\title{
Suspended-Sediment and Suspended-Sand Concentrations and Loads for Selected Streams in the Mississippi River Basin, 1940-2009
}

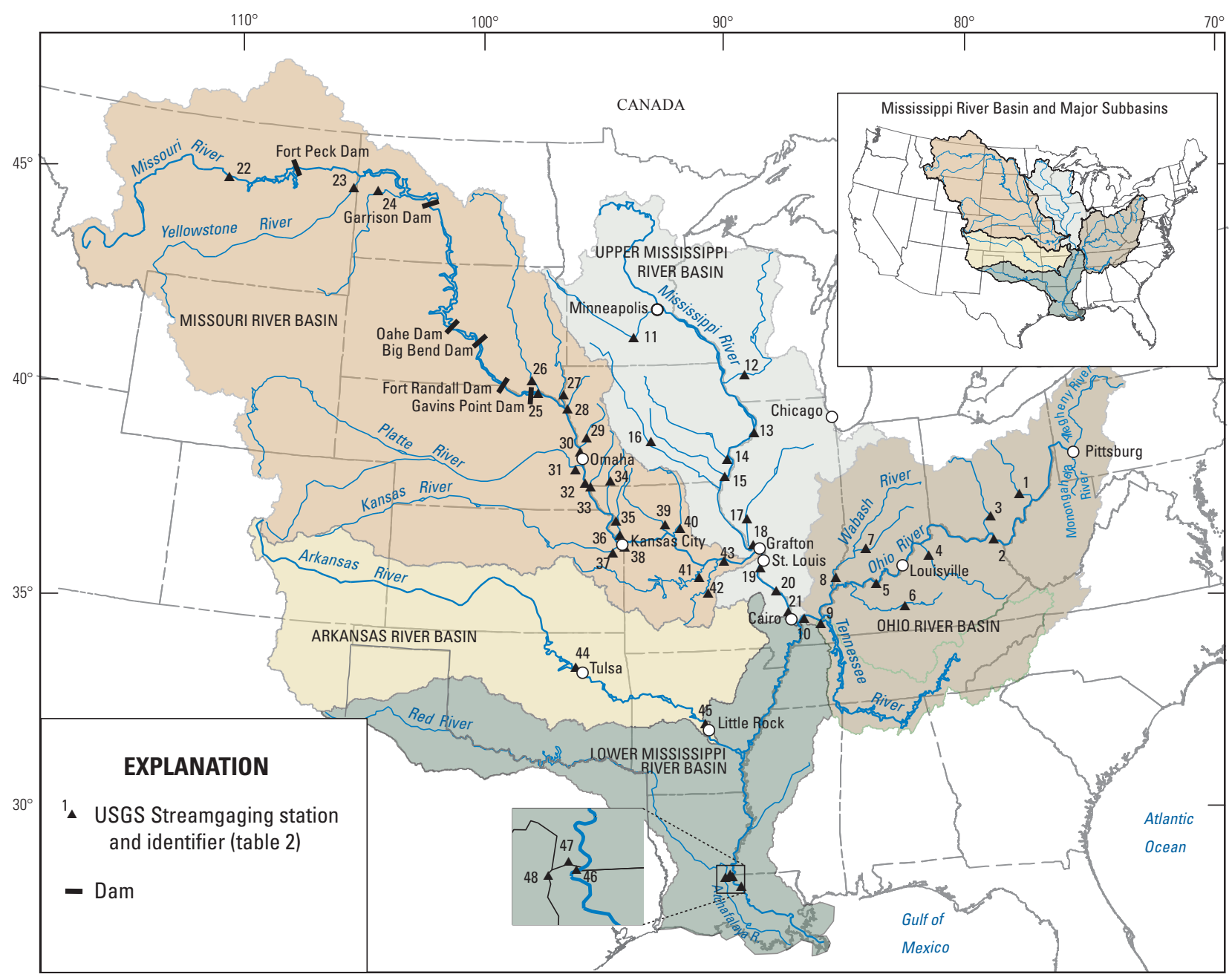

Data Series 593 
Cover Illustration: Figure 1 from this report. 


\section{Suspended-Sediment and Suspended-Sand Concentrations and Loads for Selected Streams in the Mississippi River Basin, 1940-2009}

By David C. Heimann, Teri L. Cline, and Lori M. Glaspie

Data Series 593

U.S. Department of the Interior

U.S. Geological Survey 


\section{U.S. Department of the Interior \\ KEN SALAZAR, Secretary \\ U.S. Geological Survey \\ Marcia K. McNutt, Director}

\section{U.S. Geological Survey, Reston, Virginia: 2011}

For more information on the USGS — the Federal source for science about the Earth, its natural and living resources, natural hazards, and the environment, visit http://www.usgs.gov or call 1-888-ASK-USGS.

For an overview of USGS information products, including maps, imagery, and publications, visit http://www.usgs.gov/pubprod

Any use of trade, product, or firm names is for descriptive purposes only and does not imply endorsement by the U.S. Government.

Suggested citation:

Heimann, D.C., Cline, T.L., and Glaspie, L.M., 2011, Suspended-sediment and suspended-sand concentrations and loads for selected streams in the Mississippi River Basin, 1940-2009: U.S. Geological Survey Data Series 593, 6 p. 


\section{Contents}

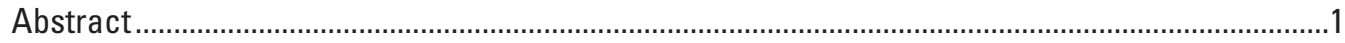

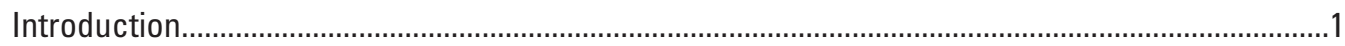

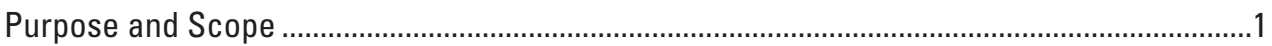

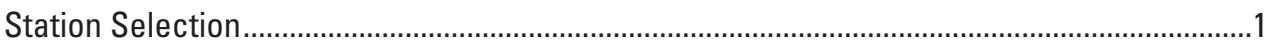

Sources of Sediment and Streamflow Data ........................................................................................

Methods of Sediment Load Estimation ...................................................................................................

Data Used in Analyses of Sediment Concentrations and Loads ........................................................3

Suspended-Sediment Concentrations and Streamflow...........................................................

Annual Suspended-Sediment Loads ......................................................................................

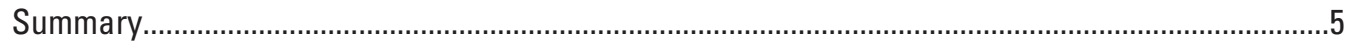

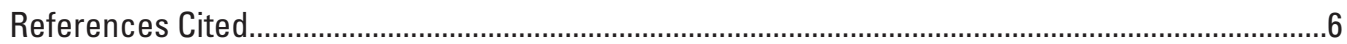

\section{Figures}

1. Map showing the Mississippi River Basin, major Mississippi River subbasins, upper Missouri River impoundments, and U.S. Geological Survey streamgaging and sediment stations included in study.

\section{Tables}

1. Selected U.S. Geological Survey streamgaging stations in the Mississippi River Basin used in study.

2. Daily-mean streamflow and suspended-sediment and suspended-sand concentration data from selected U.S. Geological Survey streamgaging stations in the Mississippi River Basin used in study (http://pubs.usgs.gov/ds/593/downloads/table2.x/sx) .............5

3. Annual-mean streamflow, flow-weighted concentrations suspended-sediment and suspended-sand loads, and annual LOADEST model characteristics for selected U.S. Geological Survey streamgaging stations in the Mississippi River Basin used in study (http://pubs.usgs.gov/ds/593/downloads/table3.x/sx) 


\section{Conversion Factors}

\begin{tabular}{lcl}
\multicolumn{1}{c}{ Inch/Pound to SI } & & \\
\hline & Bultiply & \multicolumn{1}{c}{ To obtain } \\
\hline inch (in.) & Length & millimeter $(\mathrm{mm})$ \\
mile (mi) & 25.4 & kilometer $(\mathrm{km})$ \\
\hline & 1.609 & \\
\hline square mile $\left(\mathrm{mi}^{2}\right)$ & Area & square kilometer $\left(\mathrm{km}^{2}\right)$ \\
\hline & 2.590 & cubic meter per second $\left(\mathrm{m}^{3} / \mathrm{s}\right)$ \\
\hline cubic foot per second $\left(\mathrm{ft}^{3} / \mathrm{s}\right)$ & Flow rate & \\
\hline & 0.02832 & metric ton $(\mathrm{Mt})$ \\
\hline ton, short $(2,000 \mathrm{lb})$ & Mass & \\
\hline
\end{tabular}




\title{
Suspended-Sediment and Suspended-Sand Concentrations and Loads for Selected Streams in the Mississippi River Basin, 1940-2009
}

\author{
By David C. Heimann, Teri L. Cline, and Lori M. Glaspie
}

\begin{abstract}
This report presents suspended-sediment concentration and streamflow data, describes load-estimation techniques used in the computation of annual suspended-sediment loads, and presents annual suspended-sediment loads for 48 streamgaging stations within the Mississippi River Basin. Available published, unpublished, and computed annual total suspended-sediment and suspended-sand loads are presented for water years 1940 through 2009. When previously published annual loads were not available, total suspendedsediment and sand loads were computed using available data for water years 1949 through 2009. A table of suspendedsediment concentration and daily mean streamflow data used in the computation of annual loads is presented along with a table of compiled and computed annual suspended-sediment and suspended-sand loads, annual streamflows, and flowweighted concentrations for the 48 stations.
\end{abstract}

\section{Introduction}

The U.S. Geological Survey (USGS), U.S. Army Corps of Engineers (USACE), and multiple State and local agencies have collected suspended-sediment concentration data at numerous river monitoring stations within the Mississippi River Basin (MRB) for decades. Information on sediment transport, including the temporal variability in sediment loads and concentrations, is an important tool in the management and restoration of major rivers in the MRB. The selection and compilation of sediment data are the first step in the temporal analyses of these data.

Assessments of changes in water-quality constituents, including sediment, over time are a primary goal of the U.S. Geological Survey's National Water-Quality Assessment (NAWQA) program (Gilliom and others, 2001). Therefore, suspended-sediment data were compiled for 1940 through
2009 and assessed for use in the analyses of relative subbasin sediment contributions and the temporal change in annual sediment loads, flow-weighted concentrations, flow-adjusted concentrations, and streamflows at selected MRB stations.

\section{Purpose and Scope}

This report presents suspended-sediment concentration and streamflow data, describes load-estimation techniques used in the computation of annual suspended-sediment loads, and presents annual suspended-sediment loads for 48 stations within the MRB (fig. 1). At each station, available published, unpublished, and computed annual suspended-sediment loads (SSLs) and suspended-sand (suspended material greater than 0.0625 millimeters) loads (SSDLs) are presented for water years 1940 through 2009 (water year is defined as the 12 -month period from October 1 through September 30 and is designated by the year the period ends). When previously published annual loads were not available, SSLs and SSDLs were computed using available suspended-sediment concentration (SSC) and daily streamflow data for water years 1949 through 2009. The sediment data used in the computation of SSLs and SSDLs and flow-adjusted concentrations are stored in the USGS National Water Information System (NWIS) database. The streamflow data primarily were from NWIS, but included additional sources. The data characteristics utilized in the computations of loads and flow-adjusted concentrations include SSCs, computed suspended-sand concentrations (SSDCs), and daily mean streamflows.

\section{Station Selection}

Station selection began with an assessment of published SSLs or SSCs and daily streamflow data at USGS streamgaging stations within each of the major subbasins of the MRB (fig. 1). Primary subbasins include the Ohio, upper Mississippi, Missouri, and Arkansas River Basins. A search of the 


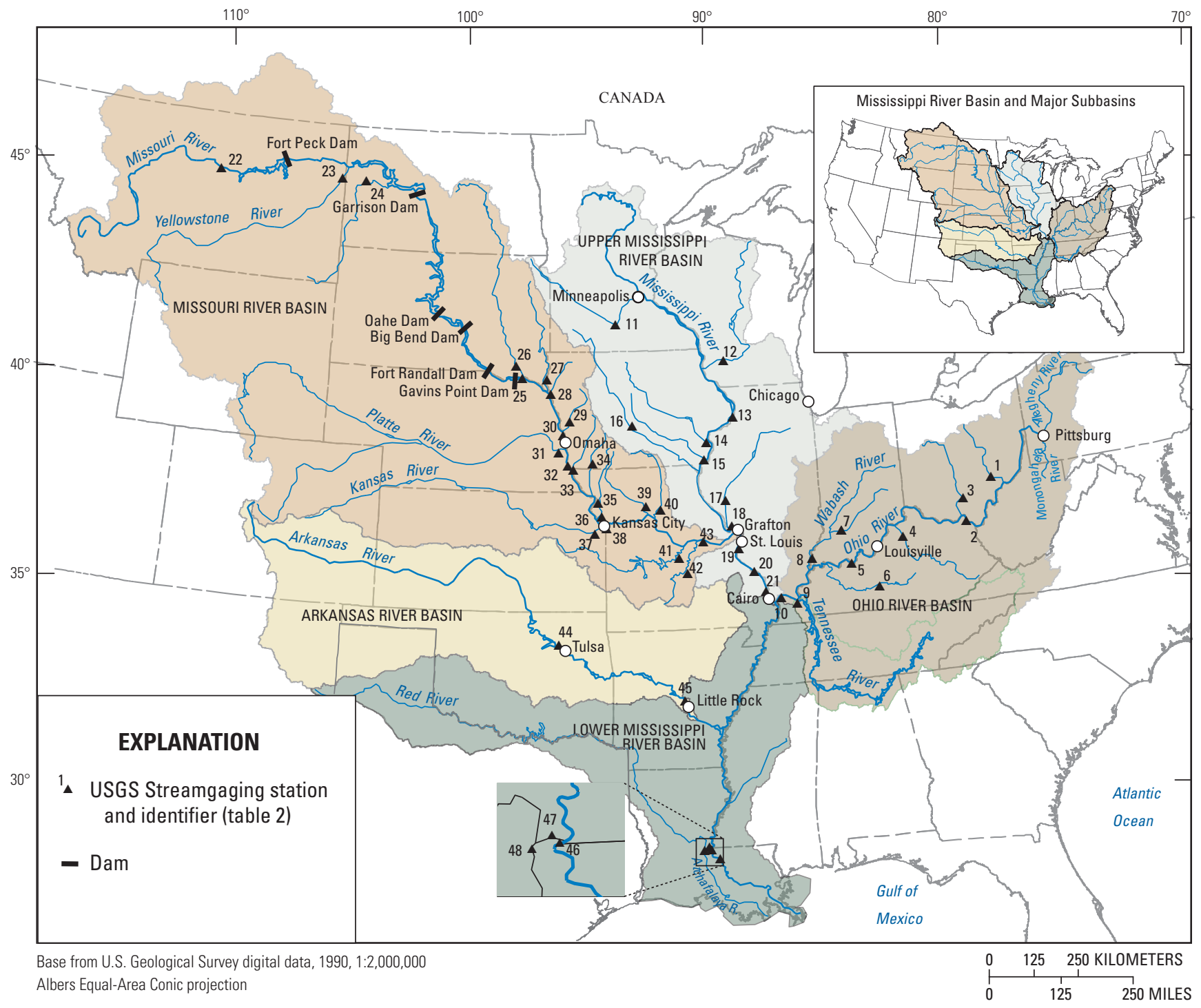

Figure 1. Mississippi River Basin, major Mississippi River subbasins, upper Missouri River impoundments, and U.S. Geological Survey streamgaging and sediment stations included in study.

USGS NWIS database was conducted for those main stem and primary tributary stations of at least 1,000 square miles with available SSLs, or SSCs and SSDCs and concurrent daily streamflow record, of at least 10 years. Further selection criteria used for those stations for which loads were not already determined included selecting stations with SSC and SSDC samples distributed throughout the water year and over the range of observed streamflows. At a minimum, data from the most-downstream station with adequate suspended sediment record from each major Mississippi River subbasin were selected for temporal analyses.

The construction of impoundments in the upper main stem of the Missouri River Basin had a substantial effect on sediment transport in the lower Missouri and Mississippi
Rivers downstream from St. Louis (Keown and others, 1981; Tuttle and Combe, 1981; Kesel, 1988; Meade and Moody, 2010). To assess changes in sediment transport in main stem and tributary sites between pre- and post-impoundment periods, available stations with continuous or non-continuous sediment record spanning both periods were selected. As with previous studies (Keown and others, 1986; Jacobson and others, 2009) the pre-impoundment period in this study was defined as pre-1953-before the closure of the Fort Randall Dam. The post-impoundment period was defined as post-1967—after the last completed reservoir, Sharpe Reservoir, formed by Big Bend Dam (fig. 1), was filled.

Final station selection and temporal analysis periods were based on maximizing the number of stations within multiple 
selected analysis periods based on record availability. Stations were selected from each major subbasin as shown in figure 1 and table 1. Published loads and data used for the computation of suspended-sediment loads and temporal changes in constituents spanned the 1940 through 2009 period.

\section{Sources of Sediment and Streamflow Data}

Suspended-sediment and streamfow data were compiled from selected stations within the MRB based on data availability and suitability for analyses of subbasin contributions and temporal changes in sediment transport. The data included SSLs, SSDLs, SSCs, sediment particle size, and annual and daily mean streamflows. Whereas total sediment transport includes bed load and suspended-sediment transport, only the suspended part of total loads are included in the data compilations.

Annual SSLs and SSDLs were obtained from preexisting published or unpublished computed daily or annual loads and loads calculated specifically for this study using SSCs or SSDCs and daily mean streamflow data. Preexisting daily published or unpublished loads were computed by the U.S. Army Corps of Engineers (U.S. Army Corps of Engineers, 1951, 1957, 1965, 1970, 1972, 1976; U.S. Army Corps of Engineers, unpublished data, 1975-81, Keown and others, 1981) or the U.S. Geological Survey (Jordan, 1965; U.S. Geological Survey, 2009; Heimann and others, 2010). Preexisting loads were available for selected stations and were computed using the tabular day-by-day method (U.S. Army Corps of Engineers, 1951, 1957, 1965, 1970, 1972, 1976; Porterfield, 1977), Load Estimator (LOADEST) regression technique (Runkel and others, 2004), or turbidity surrogate method (Rasmussen and others, 2009). Annual SSLs and SSDLs also were computed specifically for this study using the LOADEST technique, sediment concentration and particle-size data, and streamflows obtained from the U.S. Geological Survey (2009) and the Tennessee Valley Authority (Kreis Weatherington, Tennessee Valley Authority, unpublished Kentucky Lake outflow data, 1976-2009).

\section{Methods of Sediment Load Estimation}

SSLs and SSDLs were computed for those stations and years within the 1949 through 2009 water year period for which loads had not previously been determined, and sufficient concentration and streamflow data were available. The S-LOADEST version of the program LOADEST, written for the commercial statistical package TIBCO Spotfire S+ (TIBCO Software Inc., version 8.1), was used to compute load estimates as described in Heimann and others (2010).
LOADEST incorporates explanatory variables of streamflow, time, and season into one of nine predefined regression models. These models were fit to observed streamflow-SSC or streamflow-SSDC data pairs using the maximum likelihood estimation (MLE) method (Cohn and others, 1992). Model fit was judged using the Akaike Information Criterion (AIC) (Judge and others, 1988). The MLE method is contingent upon the assumption that model residuals were normally distributed and this was assessed by means of the Turnbull-Weiss likelihood ratio (Turnbull and Weiss, 1978) within S-LOADEST.

When available, the stored composite SSCs and sandpercentage values were used in determining load estimates; otherwise, the arithmetic average of sediment data from multiple-vertical samples was computed and used in load determinations. The multiple, depth-integrated (samples obtained from the entire water column) or point samples (samples obtained from selected depths or points in the water column) comprising a sediment sample were averaged (Heimann and others, 2010) to obtain a single mean concentration and particle-size fraction (if available) for a given sample date. SSDCs were determined by multiplying the SSCs by the corresponding sand fraction.

LOADEST sediment-load models were developed using a moving window approach. The load model for a given year was computed using 3, 5, or 7 years of SSC or SSDC data (determined by data availability) centered about the computation year. This method was selected to emulate the computation of existing published annual SSLs in which loads primarily were computed using data from the current water year. Because data used in load estimates for adjacent windows overlapped, only the results of the central years in nonoverlapping moving windows of the LOADEST analyses, the corresponding flow-weighted concentrations (computed as the ratio of the annual SSL or SSDL and annual streamflow), and annual-mean streamflows of these central values were used in analyses in order to avoid cross-correlation effects.

\section{Data Used in Analyses of Sediment Concentrations and Loads}

\section{Suspended-Sediment Concentrations and Streamflow}

SSC-daily mean streamflow and SSDC-daily mean streamflow data pairs for the computation of sediment loads or flow-adjusted sediment concentrations were available at 38 of the 48 USGS streamgaging stations. SSLs were published for the remaining 10 stations, but the corresponding SSC or SSDC data were not available. All SSCs, SSDCs, and corresponding daily streamflow data used in the LOADEST models or 
Table 1. Selected U.S. Geological Survey (USGS) streamgaging stations in the Mississippi River Basin used in study.

$\left[\mathrm{mi}^{2}\right.$, square mile; --, not applicable]

\begin{tabular}{|c|c|c|c|c|}
\hline $\begin{array}{c}\text { Map } \\
\text { reference } \\
\text { number } \\
\text { (fig. 1) }\end{array}$ & USGS station name & $\begin{array}{l}\text { USGS station } \\
\text { number }\end{array}$ & $\begin{array}{l}\text { Period of } \\
\text { record used in } \\
\text { analyses }\end{array}$ & $\begin{array}{l}\text { Area } \\
\left(\mathrm{mi}^{2}\right)\end{array}$ \\
\hline \multicolumn{5}{|c|}{ Ohio River Basin } \\
\hline 1 & Muskingum River at McConnelsville, Ohio & 03150000 & $1979-86$ & 7,422 \\
\hline 2 & Ohio River at Greenup Dam near Greenup, Kentucky & 03216600 & $1976-85,1997-2007$ & 62,000 \\
\hline 3 & Scioto River at Higby, Ohio & 03234500 & $1979-86$ & 5,131 \\
\hline 4 & Kentucky River at Lock 2 at Lockport, Kentucky & 03290500 & $1979-86$ & 6,180 \\
\hline 5 & Ohio River at Cannelton Dam at Cannelton, Indiana & 03303280 & $1976-86,1996-2009$ & 97,000 \\
\hline 6 & Green River at Munfordville, Kentucky & 03308500 & $1952-78,1982-93,2004-2008$ & 1,673 \\
\hline 7 & White River at Hazelton, Indiana & 03374100 & $1976-84,1991-2009$ & 11,305 \\
\hline 8 & Wabash River at New Harmony, Indiana & 03378500 & $1976-86,1997-2008$ & 29,234 \\
\hline 9 & $\begin{array}{l}\text { Tennessee River at Highway } 60 \text { near Paducah, } \\
\text { Kentucky }\end{array}$ & 03609750 & 1976-88, 1997-2009 & 40,330 \\
\hline 10 & Ohio River at Dam 53 near Grand Chain, Illinois & 03612500 & 1976-2009 & 203,100 \\
\hline \multicolumn{5}{|c|}{ Upper Mississippi River Basin } \\
\hline 11 & Minnesota River at Mankato, Minnesota & 05325000 & 1976-2009 & 14,900 \\
\hline 12 & Wisconsin River at Muscoda, Wisconsin & 05407000 & 1978-93 & 10,400 \\
\hline 13 & Mississippi River at Clinton, Iowa & 05420500 & 1943-87, 1991-2009 & 85,600 \\
\hline 14 & Iowa River at Wapello, Iowa & 05465500 & $1978-2006$ & 12,500 \\
\hline 15 & Skunk River at Augusta, Iowa & 05474000 & 1976-2009 & 4,312 \\
\hline 16 & Des Moines River near Saylorville, Iowa & 05481650 & $1978-93$ & 5,841 \\
\hline 17 & Illinois River at Valley City, Illinois & 05586100 & 1976-2009 & 26,743 \\
\hline 18 & Mississippi River below Grafton, Illinois & 05587455 & $1976-2009$ & 171,300 \\
\hline 19 & Mississippi River at Saint Louis, Missouri & 07010000 & 1949-2009 & 697,000 \\
\hline 20 & Mississippi River at Chester, Illinois & 07020500 & 1998-2009 & 708,600 \\
\hline 21 & Mississippi River at Thebes, Illinois & 07022000 & 1998-2009 & 713,200 \\
\hline \multicolumn{5}{|c|}{ Missouri River Basin } \\
\hline 22 & Missouri River near Landusky, Montana & 06115200 & $\begin{array}{l}\text { 1949-51, 1959-62, 1964-65, 1969, } \\
\text { 1971-2006 }\end{array}$ & 40,987 \\
\hline 23 & Yellowstone River near Sidney, Montana & 06329500 & 1948-2009 & 69,083 \\
\hline 24 & Little Missouri River near Watford, North Dakota & 06337000 & 1949-76 & 8,310 \\
\hline 25 & Missouri River at Yankton, South Dakota & 06467500 & $1940-59,1961-68,2001-08$ & 279,500 \\
\hline 26 & James River near Scotland, South Dakota & 06478500 & 1975-91 & 20,653 \\
\hline 27 & Big Sioux River at Akron, Iowa & 06485500 & $1941-51,1971-94$ & 7,879 \\
\hline 28 & Missouri River at Sioux City, Iowa & 06486000 & 1976-2000, 2004-09 & 314,600 \\
\hline 29 & Boyer River at Logan, Iowa & 06609500 & $1940-51,1969-74,2004-09$ & 871 \\
\hline 30 & Missouri River at Omaha, Nebraska & 06610000 & 1940-2009 & 322,800 \\
\hline 31 & Platte River at Louisville, Nebraska & 06805500 & $1940-51,1953-71,1973-2009$ & 85,370 \\
\hline 32 & Missouri River at Nebraska City, Nebraska & 06807000 & $1976-2009$ & 410,000 \\
\hline 33 & Nishnabotna River above Hamburg, Iowa & 06810000 & $1940-51,1982-93,2004-09$ & 2,806 \\
\hline 34 & Nodaway River at Clarinda, Iowa & 06817000 & $1976-91$ & 762 \\
\hline 35 & Missouri River at Saint Joseph, Missouri & 06818000 & 1949-2009 & 426,500 \\
\hline 36 & Platte River at Sharps Station, Missouri & 06821190 & 1980-91 & 2,380 \\
\hline
\end{tabular}


Table 1. Selected U.S. Geological Survey (USGS) streamgaging stations in the Mississippi River Basin used in study.Continued

$\left[\mathrm{mi}^{2}\right.$, square mile; --, not applicable]

\begin{tabular}{|c|c|c|c|c|}
\hline $\begin{array}{c}\text { Map } \\
\text { reference } \\
\text { number } \\
\text { (fig. 1) }\end{array}$ & USGS station name & $\begin{array}{l}\text { USGS station } \\
\text { number }\end{array}$ & $\begin{array}{l}\text { Period of } \\
\text { record used in } \\
\text { analyses }\end{array}$ & $\begin{array}{l}\text { Area } \\
\left(\mathrm{mi}^{2}\right)\end{array}$ \\
\hline \multicolumn{5}{|c|}{ Missouri River Basin-Continued } \\
\hline 37 & Kansas River at DeSoto, Kansas & 06892350 & $1949-74,1976-91,2000-05$ & 59,756 \\
\hline 38 & Missouri River at Kansas City, Missouri & 06893000 & $1949-81,1988-2009$ & 484,100 \\
\hline 39 & Grand River near Sumner, Missouri & 06902000 & 1975-91 & 6,880 \\
\hline 40 & Chariton River near Prairie Hill, Missouri & 06905500 & $1978-86$ & 1,870 \\
\hline 41 & Osage River below Saint Thomas, Missouri & 06926510 & $1975-91$ & 14,584 \\
\hline 42 & Gasconade River at Jerome, Missouri & 06933500 & $1978-91$ & 2,840 \\
\hline 43 & Missouri River at Hermann, Missouri & 06934500 & 1949-2009 & 522,500 \\
\hline \multicolumn{5}{|c|}{ Arkansas River Basin } \\
\hline 44 & Arkansas River at Tulsa, Oklahoma & 07164500 & $1950-95$ & 74,615 \\
\hline 45 & $\begin{array}{l}\text { Arkansas River at David D. Terry Lock and Dam } \\
\text { below Little Rock, Arkansas }\end{array}$ & 07263620 & $1976-2009$ & 158,429 \\
\hline \multicolumn{5}{|c|}{ Lower Mississippi River Basin } \\
\hline 46 & Mississippi River at Tarbert Landing, Mississippi & 07295100 & $1950-2009$ & $1,124,900$ \\
\hline 47 & $\begin{array}{l}\text { Old River Outflow Channel near Knox Landing, } \\
\text { Louisiana }\end{array}$ & 310355091411500 & 1966-2009 & $\begin{array}{l}\text { Indeter- } \\
\text { minate }\end{array}$ \\
\hline 48 & Atchafalaya River at Simmesport, Louisiana & 07381490 & 1952-2009 & $87,570^{1}$ \\
\hline
\end{tabular}

${ }^{1}$ Drainage area does not include that area apportioned to the river based on the fraction of streamflow diverted from the Mississippi River main stem.

flow-adjusted concentration analyses are summarized by site in table 2 (http://pubs.usgs.gov/ds/593/downloads/table2.xlsx).

\section{Annual Suspended-Sediment Loads}

Preexisting and computed annual SSLs and annual SSDLs (in tons) were compiled for 48 USGS streamgaging stations (fig. 1, table 1) in the Mississippi River Basin for the period 1940 through 2009 (table 3). The annual mean streamflows and flow-weighted concentrations corresponding to the years of available sediment loads also are included in table 3 (http://pubs.usgs.gov/ds/593/downloads/table3.xlsx). The period of sediment load record from each of the 48 stations available for use in temporal analyses are presented in table 1.

\section{Summary}

This report presents suspended-sediment concentration and streamflow data, describes load-estimation techniques used in the computation of annual suspended-sediment loads, and presents annual suspended-sediment loads for 48 stations within the Mississippi River Basin. Available published, unpublished, and computed annual suspended-sediment and suspended-sand loads are presented for water years 1940 through 2009. When previously published annual loads were not available, total suspended-sediment and sand loads were computed using available data for water years 1949 through 2009.

Annual sediment load values were computed specifically for this study using the Load Estimation (LOADEST) technique and utilized sediment concentration, particle size, and streamflow data obtained from the USGS National Water Information System, U.S. Army Corps of Engineers, and the Tennessee Valley Authority. A table of suspended-sediment concentration and daily mean streamflow data used in the computation of annual loads is presented along with a table of compiled and computed annual suspended-sediment and suspended-sand loads, annual streamflows, and flow-weighted concentrations for the 48 stations. 


\section{References Cited}

Cohn, T.A., Gilroy, E.J., and Baier, W.G., 1992, Estimating fluvial transport of trace constituents using a regression model with data subject to censoring: Proceedings of the Joint Statistical Meeting, Boston, August 9-13, 1992, p. $142-151$.

Gilliom, R.J., Hamilton, P.A., and Miller, T.L., 2001, The National Water-Quality Assessment Program-Entering a new decade of investiagations: U.S. Geological Survey Fact Sheet $071-01,6 \mathrm{p}$.

Heimann, D.C., Rasmussen, P.P., Cline, T.L., Pigue, L.M., and Wagner, H.R., 2010, Characteristics of sediment data and annual suspended-sediment loads and yields for selected lower Missouri River mainstem and tributary stations, 1976-2008: U.S. Geological Survey Data Series Report 530, 58 p. (Also available at http://pubs.usgs.gov/ $d s / 530 /$.

Jacobson, R.B., Blevins, D.W., and Bitner, C.J., 2009, Sediment regime constraints on river restoration-An example from the lower Missouri River: Geological Society of America Special Papers 451, 22 p.

Jordan, P.R., 1965, Fluvial Sediment of the Mississippi River at St. Louis, Missouri: U.S. Geological Survey WaterSupply Paper 1802, 89 p.

Judge, G.G., Hill, R.C., Griffiths, W.E., Lutkepohl, H., and Lee, T.C., 1988, Introduction to the theory and practice of econometrics ( $2 \mathrm{~d}$ ed.): New York, John Wiley and Sons, $1,024 \mathrm{p}$.

Keown, M.P., Dardeau, E.A., Jr., and Causey, E.M., 1981, Characterization of the suspended-sediment regime and bed-material gradation of the Mississippi River Basin: U.S. Army Corps of Engineers, Waterway experiment Station, Report 1, Potamology Program, variously paged.

Keown, M.P., Dardeau, E.A., Jr., and Causey, E.M., 1986, Historic trends in the sediment flow regime of the Mississippi River: Water Resources Research, 22:1555-1564.

Kesel, R.H., 1988, The decline in the suspended sediment load of the lower Mississippi River and its influence on adjacent wetlands, Environmental Geology and Water Sciences 11:271-281.

Meade, R.H., and Moody, J.A., 2010, Causes for the decline of suspended-sediment discharge in the Mississippi River system, 1940-2007, Hydrological Processes 24:35-49.

Turnbull, B.W., and Weiss, L., 1978, A likelihood ratio statistic for testing goodness of fit with randomly censored data: Biometrics, v. 34, p. 367-375.
Tuttle, J.R., and Combe, A.J., 1981, Flow regime and sediment load affected by alterations of the Mississippi River, in Proceedings of the National Symposium on Freshwater inflow to Estuaries, Cross, R.D., and Williams, D., eds., Fish and Wildlife Service, Office of Biological Services report FWS/OBS-81/04, p. 334-348.

Porterfield, G., 1977, Computation of Fluvial-sediment Discharge, Techniques of Water-Resources Investigations of the US Geological Survey, book 3, chap. C3, 66 p.

Rasmussen, P.P., Gray, J.R., Glysson, G.D., and Ziegler, A.C., 2009, Guidelines and procedures for computing time-series suspended sediment concentrations and loads from instream turbidity-sensor and streamflow data: U.S. Geological Survey Techniques and Methods, book 3, chap. C4, $54 \mathrm{p}$.

Runkel, R.L., Crawford, C.G., and Cohn, T.A., 2004, Load Estimator (LOADEST) - A FORTRAN program for estimating constituent loads in streams and rivers: U.S. Geological Survey Techniques and Methods, book 4, chap. A5, 69 p.

U.S. Army Corps of Engineers, 1951, Suspended Sediment in the Missouri River-Daily Record for Water Years 1937-1948: Omaha, Nebraska, U.S. Army Corps of Engineers, Missouri River Division, 219 p.

U.S. Army Corps of Engineers, 1957, Suspended Sediment in the Missouri River-Daily Record for Water Years 1949-1954: Omaha, Nebraska, U.S. Army Corps of Engineers, Missouri River Division, $210 \mathrm{p}$.

U.S. Army Corps of Engineers, 1965, Suspended Sediment in the Missouri River-Daily Record for Water Years 1955-1959: Omaha, Nebraska, U.S. Army Corps of Engineers, Missouri River Division, 118 p.

U.S. Army Corps of Engineers, 1970, Suspended Sediment in the Missouri River-Daily Record for Water Years 1960-1964: Omaha, Nebraska, U.S. Army Corps of Engineers, Missouri River Division, $190 \mathrm{p}$.

U.S. Army Corps of Engineers, 1972, Suspended Sediment in the Missouri River-Daily Record for Water Years 1965-1969: Omaha, Nebraska, U.S. Army Corps of Engineers, Missouri River Division, 248 p.

U.S. Army Corps of Engineers, 1976, Suspended Sediment in the Missouri River-Daily Record for Water Years 1970-1974: Kansas City, Missouri, U.S. Army Corps of Engineers, Missouri River Division, 201 p.

U.S. Geological Survey, 2009, USGS water data for the Nation: U.S. Geological Survey National Water Information System Web interface, accessed December 23, 2009, at http://waterdata.usgs.gov/nwis/. 
Publishing support provided by:

Rolla and Lafayette Publishing Service Centers

For more information concerning this publication, contact:

Director, U.S. Geological Survey

Missouri Water Science Center

1400 Independence Road

Rolla, M0 65401

(573) 308-3667

Or visit the Missouri Water Science Center website at: http://mo.water.usgs.gov 

